\section{Nina Dwi Lestari}

Departemen Jiwa dan Komunitas, Program Studi Ilmu Keperawatan, Fakultas Kedokteran dan IImu Kesehatan, Universitas Muhammadiyah Yogyakarta Jl. Lingkar Selatan, Tamantirto, Kasihan, Bantul, Yogyakarta, Indonesia

Email: gavinnaufal@yahoo.com

\title{
Analisis Determinan Gizi Kurang pada Balita di Kulon Progo, Yogyakarta
}

Info Artikel:

Masuk : : 2 September 2016

Revisi : : 21 November 2016

Diterima : 28 November 2016

DOI Number : 10.18196/ijnp.1146

\section{ABSTRAK}

Masalah gizi kurang balita merupakan masalah aktual di wilayah Kulon Progo, Yogyakarta. Tujuan penelitian ini untuk mengetahui faktor yang mempengaruhi status gizi balita. Penelitian ini menggunakan cross sectional, sampel balita $12-59$ bulan sebanyak 155 orang. Data diperoleh melalui kuesioner, status gizi diukur dengan indeks Berat Badan/Umur. Hasil menunjukkan terdapat hubungan bermakna antara usia balita, riwayat pemberian ASI, asupan makanan, persepsi ibu, pola pengasuhan dengan status gizi balita. Faktor dominan yang mempengaruhi status gizi adalah asupan makanan. Diperlukan peran perawat komunitas dalam edukasi dan pemberdayaan untuk meningkatkan status gizi balita.

Kata kunci: faktor status gizi, gizi kurang, balita

\section{ABSTRACT}

Undernutrition was still a prior problem in Kulon Progo,Yogyakarta. The objectives of this study were to determine nutritional status in children under five years and related factors. Cross sectional study was conducted with 155 children under five years. Nutritional status was assessed using anthropometric measurement. There was a significant association between child's age, exclusife breastfeeding, child's dietary intake, caregivers' practice and mother's perception with child's nutritional status and child's dietary energy intake was the most factor that significant correlated. These findings indicates that the roles of community nurses are needed to improves children nutritional status using education and partnership.

Keywords: factors of nutritional status, undernutrition, children under five years 


\section{NURSING PRACTICES}

\section{PENDAHULUAN}

Masalah gizi kurang pada balita masih menjadi masalah mendasar di dunia. WHO (2013), jumlah penderita kurang gizi di dunia mencapai 104 juta anak. Riskesdas (2013), prevalensi balita dengan berat kurang (under weight) adalah berjumlah 19,6\%. Sebanyak 13,9\% balita memiliki status gizi kurang. Dinkes Kab. Kulon Progo (2014) melaporkan jumlah balita gizi kurang adalah sebanyak 10,13\%. Kondisi gizi kurang pada balita, dimungkinkan terjadi karena interaksi dari beberapa faktor diantaranya asupan makanan yang tidak adekuat, pemberian ASI yang tidak ekslusif, penyakit infeksi yang diderita balita, pola pengasuhan keluarga, pelayanan kesehatan, jumlah anggota keluarga, tingkat pendidikan ibu, persepsi ibu terkait gizi, sosial ekonomi yang rendah dan budaya (UNICEF, 2013, Naghaspour et al, 2014).

Penyebab dasar terjadinya gizi kurang pada balita adalah status ekonomi yang rendah (UNICEF, 2013). Kondisi kemiskinan mempengaruhi kondisi ketahanan pangan dalam keluarga (Almatsier, 2009). Penyebab dasar lain yang berkontribusi dalam terjadinya masalah gizi kurang pada balita adalah pendidikan (UNICEF, 2013). Hasil penelitian Handono (2012), menunjukkan bahwa pendidikan orang tua terutama ibu berpengaruh secara signifikan terhadap status gizi balita.

Wong et al (2014), masalah gizi kurang pada balita secara langsung disebabkan oleh anak tidak mendapatkan cukup asupan makanan yang mengandung gizi seimbang. Gizi kurang juga diakibatkan oleh adanya infeksi pada balita. Infeksi akan mengganggu metabolisme, keseimbangan hormon dan fungsi imunitas (Bantamen, Belaynew, \& Dube, 2014).

Faktor lain yang erat kaitannya dengan gizi kurang adalah pola pengasuhan anak dalam keluarga. Penelitian yang dilakukan oleh Maseta, Makau dan Omwega (2008) menunjukkan bahwa terdapat hubungan yang signifikan antara pola pengasuhan anak dan praktik perawatan kesehatan anak dalam keluarga dengan status nutrisi pada anak usia 6-36 bulan di Tanzania.

Faktor selanjutnya adalah pelayanan kesehatan. Rendahnya pemanfaatan pelayanan kesehatan berpengaruh sebesar 60-70\% kematian balita dengan gizi kurang (UNICEF, 2013).
Melihat jumlah angka kejadian gizi kurang pada Balita di wilayah Kulon Progo, Yogyakarta yang masih tinggi dan masalah gizi disebabkan oleh multifaktorial, oleh karena itu diperlukan penelitian mengenai determinan gizi kurang pada balita di wilayah ini. Penelitian ini bertujuan untuk menganalisis faktor-faktor yang berpengaruh terhadap status gizi balita di wilayah Kulon Progo, Yogyakarta.

\section{METODE}

Desain penelitian yang digunakan adalah Cross Sectional dengan jumlah sampel 155 orang yang terdiri dari balita usia 12-59 bulan beserta keluarganya, yang diambil dengan metode proportional cluster sampling. Variabel bebas pada penelitian ini adalah usia balita, jenis kelamin, riwayat penyakit infeksi, pendidikan ibu, status perekonomian keluarga, jumlah anggota keluarga, asupan makanan, persepsi ibu terkait status gizi, pola pengasuhan keluarga terkait gizi, pelayanan kesehatan dan budaya. Variabel terikat pada penelitian ini adalah status gizi.

Instrumen pengambilan data variabel terikat menggunakan kuesioner yang dikembangkan peneliti yang telah dinyatakan valid dan reliable melalui uji validitas dan reliabilitas. Variabel asupan makanan diukur menggunakan foodrecords selama 2 hari berturutturut. Variabel status gizi diukur berdasarkan indeks antropometri BB/ $U$, dengan klasifikasi status gizi baik: -2 SD s.d + 2 SD. Status gizi kurang: $<-2$ SD s.d $<-3$ SD, status gizi buruk: d" -3 SD. Status gizi dikelompokkan menjadi gizi baik dan gizi kurang (gizi kurang dan gizi buruk).

Analisis data meliputi univariat, bivariat dan multivariat. Analisis bivariat menggunakan Chi Square, dan analisis multivariat menggunakan regresi logistik berganda. Penelitian ini memperhatikan aspek etik dalam pengambilan data meliputi menghargai harkat dan martabat manusia, kemanfaatan, keadilan dan informed consent dan telah lolos kaji etik dengan no 0231/ UN2. F12.D / HKP. 02.04/ 2015

\section{HASIL}

Berdasarkan Tabel 1 dapat disimpulkan bahwa mayoritas balita yang menjadi responden adalah berusia 
pra sekolah. Berdasarkan jenis kelamin, prosentase lakilaki dan perempuan hampir sama. Responden lebih banyak yang memiliki riwayat ASI ekslusif dibandingkan yang tidak ekslusif. Sebagian besar responden pernah mengalami penyakit infeksi dalam 6 bulan terakhir dan mayoritas memiliki status gizi baik.

Tabel 1. Karakteristik Balita

\begin{tabular}{lcc}
\hline \multicolumn{1}{c}{ Karakteristik Balita } & Frekuensi & Prosentase \\
\hline Usia balita & & \\
Todler(12-36 bulan) & 65 & $41,9 \%$ \\
Preschool(37-59 bulan) & 90 & $58,1 \%$ \\
\hline Jenis kelamin & 78 & $50,3 \%$ \\
Perempuan & 77 & $49,7 \%$ \\
Laki-laki & & \\
\hline Riwat pemberian ASI & 64 & $41,3 \%$ \\
Nonekslusif & 91 & $58,7 \%$ \\
Ekslusif & & \\
\hline Riwayat penyakit infeksi & 103 & $66,5 \%$ \\
Ada & 52 & $33,5 \%$ \\
Tidak ada & & \\
\hline Status Gizi & 131 & $84,5 \%$ \\
Gizi baik & 24 & $15,5 \%$ \\
Gizi kurang & &
\end{tabular}

Tabel 2. Karakteristik Keluarga

\begin{tabular}{lcc}
\hline \multicolumn{1}{c}{ Karakteristik Keluarga } & Frekuensi & Prosentase \\
\hline Pendidikan ibu & & \\
Rendah & 58 & $37,4 \%$ \\
Tinggi & 97 & $62,6 \%$ \\
\hline Status ekonomi & & \\
$\quad$ <UMK & 81 & $52,3 \%$ \\
$\geq$ UMK & 74 & $47,7 \%$ \\
\hline Jumlah anggota keluarga & & \\
Besar & 65 & $41,9 \%$ \\
Kecil & 90 & $58,1 \%$ \\
\hline
\end{tabular}

Tabel 3. Analisis Bivariat Faktor yang Mempengaruhi Gizi Kurang Balita

\begin{tabular}{lll}
\hline Variabel & OR & P value \\
\hline Usia balita & 3,347 & 0,014 \\
\hline Jenis kelamin & 0,662 & 0,484 \\
\hline Riwayat ASI & 4,340 & 0,003 \\
\hline Riwayat infeksi & 0,661 & 0,496 \\
\hline Pendidikan ibu & 0,646 & 0,497 \\
\hline Status ekonomi & 0,737 & 0,643 \\
\hline Jumlah anggota keluarga & 1,795 & 0,273 \\
\hline Asupan makanan & 9,677 & 0,000 \\
\hline Persepsi ibu & 3,742 & 0,017 \\
\hline Pola asuh & 2,955 & 0,045 \\
\hline Pelayanan kesehatan & 1,379 & 0,621 \\
\hline Budaya & 1,442 & 0,571 \\
\hline
\end{tabular}

Berdasarkan tabel 2, dapat dilihat bahwa mayoritas ibu memiliki pendidikan tinggi, dengan status ekonomi lebih banyak yang kurang dari upah minimum kabupaten. Jumlah anggota keluarga yang dimiliki mayoritas adalah kurang dari 4 orang.

Tabel 3 menunjukkan bahwa variabel yang berhubungan secara bermakna dengan gizi kurang balita adalah variabel usia balita, riwayat pemberian ASI, asupan makanan, persepsi ibu terkait status gizi balita, dan pola pengasuhan keluarga terkait gizi ( $p$ value $<0,05$ ).

Tabel 4 Hasil akhir analisis multivariat regresi logistic

\begin{tabular}{llll}
\hline Variabel & $\begin{array}{l}\mathrm{B} \\
\text { (koefisien) }\end{array}$ & P value & OR $(\mathrm{Cl} 95 \%)$ \\
\hline Usia balita & 2,406 & 0,001 & $\begin{array}{l}11,093 \\
(2,804-43,883)\end{array}$ \\
& & & 9,572 \\
& 2,259 & 0,001 & $(2,439-37,576)$ \\
\hline $\begin{array}{llll}\text { Riwayat } \\
\text { pemberian ASI }\end{array}$ & & $\begin{array}{l}11,927 \\
(3,467-41,029)\end{array}$ \\
\hline Asupan makanan & 2,479 & 0,000 & 4,619 \\
& & 0,024 & $(1,220-17,487)$ \\
\hline $\begin{array}{l}\text { Persepsi ibu } \\
\text { terkait status gizi }\end{array}$ & 1,530 & 0,084 & 3,082 \\
\hline $\begin{array}{l}\text { Pola pengasuhan } \\
\text { keluarga terkait }\end{array}$ & 1,126 & & $(0,861-11,030)$ \\
gizi & & 0,000 & 0,001
\end{tabular}

Berdasarkan analisis menggunakan regresi logistik berganda diperoleh bahwa variabel yang paling dominan mempengaruhi status gizi balita adalah asupan makanan $(\mathrm{OR}=11,927)$. Asupan makanan yang kurang baik, berpeluang 11,9 kali lebih besar mendapatkan status gizi kurang dibandingkan dengan asupan makan yang baik.

\section{PEMBAHASAN}

Hasil analisis statistik menunjukkan bahwa terdapat hubungan yang signifikan antara usia dengan gizi kurang pada balita dengan $p$ value 0,014 ( $p$ value $<0,05$ ) dengan nilai OR sebesar 3,347. Balita yang berusia 12-36 bulan beresiko 3,34 kali lebih besar mendapatkan gizi kurang dibandingkan dengan balita yang berusia 37-59 bulan. Stanhope dan Lancaster (2012) menjelaskan bahwa balita memiliki faktor resiko resiko biologi yang meliputi faktor genetik atau fisik 


\section{NURSING PRACTICES}

yang ikut berperan dalam timbulnya resiko tertentu yang mengancam kesehatan. Usia balita yang masih muda menyebabkan sistem kekebalan tubuh yang belum berkembang. Hal ini menyebabkan balita lebih mudah terkena masalah nutrisi.

Hasil analisis hubungan antara jenis kelamin dengan gizi kurang balita menunjukkan bahwa tidak terdapat hubungan yang signifikan antara jenis kelamin dengan status gizi balita ( $p$ value $=0,528$ ). Hal ini disebabkan karena tidak adanya perbedaan pandangan nilai yang dianut keluarga terhadap keberadaan seorang anak lakilaki dan perempuan di wilayah ini, sehingga perlakuan keluarga dalam hal pola asuh, pemberian makan, kesempatan mengakses sumber-sumber kesehatan adalah sama untuk anak laki-laki dan perempuan.

Menurut UNICEF (2011), gender sangat berkaitan dengan nilai (value) terhadap seorang anak. Ketidaksetaraan gender terjadi apabila terdapat penilaian yang berbeda antara anak laki-laki dan perempuan dalam suatu komunitas yang menyebabkan anak lakilaki dan perempuan mendapatkan perlakuan yang berbeda, perawatan kesehatan yang berbeda, dan perbedaan aksesibilitas terhadap sumber-sumber. Hal ini menyebabkan ketidaktepatan dalam pengasuhan anak dan rendahnya kemampuan dalam mengakses pelayanan kesehatan.

Hasil analisis mengenai hubungan riwayat pemberian ASI dengan gizi kurang balita menunjukkan bahwa terdapat hubungan yang signifikan antara riwayat pemberian ASI dengan status gizi balita ( $p$ value $=, 003$ ). Balita dengan riwayat ASI nonekslusif berpeluang mengalami gizi kurang sebanyak 4,34 kali lebih besar dibandingkan dengan balita dengan riwayat ASI ekslusif.

Hasil penelitian ini didukung oleh Nakamori et al (2010), bahwa bayi yang tidak mendapatkan ASI ekslusif memiliki peluang 3,95 kali mengalami underweight dibandingkan dengan bayi yang mendapatkan ASI ekslusif. Hal ini disebabkan karena pemberian ASI ekslusif menurunkan angka kejadian penyakit infeksi yang berhubungan dengan kondisi status gizi balita. ASI ekslusif akan meningkatkan sistem imunitas bayi, sehingga daya tahan tubuh terhadap infeksi akan meningkat.
Hasil analisis mengenai hubungan riwayat penyakit infeksi dengan gizi kurang pada balita menunjukkan tidak ada hubungan yang signifikan antara riwayat penyakit infeksi dengan gizi kurang balita ( $p$ value $=0,496$ ). Hal ini disebabkan karena upaya pencegahan terhadap kasus gizi kurang sudah dilaksanakan dengan baik oleh keluarga balita, misalnya dengan pemberian ASI secara ekslusif. Hasil penelitian ini sejalan dengan penelitian Nakamori et al (2010) bahwa penyakit infeksi tidak berpengaruh terhadap kejadian underweight disebabkan adanya tindakan pencegahan yang secara dini dilakukan untuk mencegah balita mendapatkan underweight seperti melalui pemberian ASI ekslusif.

Hasil analisis menunjukkan bahwa tidak terdapat hubungan yang bermakna antara pendidikan ibu dengan gizi kurang balita ( $p$ value $=0,497$ ). Ini disebabkan karena ibu tidak mendapatkan pendidikan mengenai status gizi di pendidikan formal. Ibu dengan pendidikan rendah bisa mendapatkan informasi terkait gizi melalui pendidikan informal melalui petugas kesehatan di posyandu, puskesmas atau rumah sakit dengan kemasan informasi yang mudah diserap dan dimengerti tanpa harus dengan pendidikan tinggi. Penelitian ini didukung oleh hasil penelitian Charmarbaglawa, Ranger, Waddington, dan White (2010), bahwa pendidikan ibu tidak berpengaruh terhadap status gizi balita. Kondisi ini disebabkan oleh kualitas pendidikan yang ditempuh dalam pendidikan formal yang kurang baik dan ibu tidak mendapatkan informasi terkait gizi di pendidikan formal, akan tetapi terdapat informasi gizi yang mudah diserap oleh ibu meskipun dengan pendidikan rendah di luar pendidikan formal.

Hasil analisis statistik menunjukkan tidak ada hubungan yang signifikan atara status ekonomi dengan gizi kurang balita ( $p$ value $=0,643$ ). Hal ini disebabkan keluarga dengan status perekonomian rendah justru mampu mengalokasikan keuangan keluarga dengan lebih teliti dan hati-hati. Berusaha mengatur pengeluaran dengan alokasi utama adalah untuk kebutuhan primer seperti kebutuhan makanan. Charmarbaglawa, Ranger, Waddington, dan White (2010) mengemukakan bahwa dalam mengalokasikan penghasilan, keluarga dengan 
penghasilan yang kurang akan lebih hati-hati dalam pengeluaran sehingga pengeluaran tidak melebihi dari pendapatan.

Status perekonomian keluarga tidak memiliki hubungan yang signifikan dengan status gizi disebabkan oleh adanya pemanfaatan lahan yang baik oleh keluarga dalam menunjang nutrisi anak. Hal ini sesuai dengan penelitian Annim dan Imai (2014) bahwa terdapat hubungan yang signifikan antara kepemilikan lahan pertanian dengan kondisi malnutisi. Meningkatnya ukuran lahan pertanian akan menurunkan insiden malnutrisi.

Hasil analisis statistik menunjukkan tidak ada hubungan yang yang signifikan antara jumlah anggota keluarga dengan gizi kurang pada balita ( $p$ value $=0,273$ ). Hal ini disebabkan karena terdapat keluarga balita dengan komposisi jumlah anggota keluarga yang produktif bekerja lebih banyak, sehingga akan meningkatkan pendapatan keluarga yang menyebabkan kondisi status gizi anak menjadi lebih baik.

Hasil penelitian ini didukung oleh Charmarbaglawa, Ranger, Waddington, dan White (2010) menunjukkan bahwa pada keluarga dengan jumlah anggota keluarga yang besar akan tetapi memiliki lebih banyak anggota keluarga yang bekerja (rasio antara anggota keluarga yang tidak bekerja dibandingkan yang bekerja lebih kecil) menyebabkan pendapatan keluarga dan status ekonominya meningkat. Hal ini menyebabkan kondisi kesehatan anak dan status gizinya menjadi lebih baik.

Hasil analisis statistik menunjukkan bahwa terdapat hubungan yang signifikan antara asupan makanan dengan gizi kurang balita ( $p$ value $=0,000$ ). Balita dengan asupan makanan yang kurang memiliki peluang 9,677 kali lebih besar mendapatkan gizi kurang dibandingkan dengan balita yang mempunyai asupan makanan yang baik $(O R=9,677)$. Makanan yang seimbang dibutuhkan tubuh untuk pemeliharaan, perbaikan sel-sel tubuh, pertumbuhan dan perkembangan (UNICEF, 2013).

Hasil analisis variabel persepsi ibu balita terhadap gizi kurang balita menunjukkan bahwa terdapat hubungan yang signifikan antara persepsi ibu terkait status gizi dengan status gizi balita ( $p$ value $=0,017$ )
Ibu dengan persepsi yang kurang baik terhadap status gizi berpeluang 3,7 kali lebih besar mendapatkan gizi kurang dibanding ibu dengan persepsi yang baik terkait status gizi $(\mathrm{OR}=3,742)$.

Persepsi orang tua yang merasakan bahwa kondisi gizi kurang pada balita itu merupakan kondisi rentan dan serius yang berpotensi menimbulkan dampak buruk bagi balita, akan melakukan tindakan pencegahan ataupun pencarian pengobatan apabila orang tua tersebut memiliki persepsi yang kuat terhadap manfaat yang dirasakan dari tindakan yang diambil dibandingkan persepsi hambatan yang akan dihadapi. Orang tua yang memiliki persepsi manfaat yang kuat terhadap manfaat tindakan pencegahan gizi kurang, akan selalu membawa balitanya ke posyandu atau puskesmas untuk melakukan kontrol status gizi anak balitanya ke pelayanan kesehatan, memberikan asupan makanan yang baik, dan melakukan pola asuh nutrisi yang baik (Hayati, 2014)

Hasil analisis menunjukkan terdapat hubungan yang signifikan antara pola asuh keluarga terkait gizi dengan gizi kurang pada balita ( $p$ value $=0,045$ ). Pola asuh keluarga terkait status gizi yang kurang baik berpeluang 2,96 kali lebih besar mendapatkan gizi kurang dibanding dengan pola asuh keluarga yang baik $(\mathrm{OR}=2,955)$.

Hasil penelitian ini didukung oleh penelitian Kartika et al (2000) bahwa terdapat hubungan antara pola asuh makan dengan status gizi balita. Kondisi usia balita yang masih berada pada tahap ketergantungan dalam pemenuhan kebutuhan dasarnya terhadap orang tua atau pengasuh, membuat asupan makanan sangat tergantung dengan bagaimana cara pengasuhan, cara memberi makan dan cara perawatan kesehatan oleh orang tua atau pengasuh.

Hasil analisis menunjukkan tidak ada hubungan yang signifikan antara pelayanan kesehatan dengan gizi kurang pada balita ( $p$ value $=0,621$ ). Hal ini disebabkan karena kondisi status perekonomian keluarga balita yang sebagian besar memiliki penghasilan kurang dari UMK, yang menyebabkan kurangnya akses keluarga terhadap pelayanan kesehatan. Kemampuan keluarga untuk mengakses pelayanan kesehatan berkaitan 


\section{NURSING PRACTICES}

dengan ketersediaan sarana pelayanan kesehatan dan kemampuan ekonomi untuk membayar biaya pelayanan kesehatan (Sartika, 2010).

Hasil penelitian ini menunjukkan tidak ada hubungan antara budaya dengan gizi kurang pada balita ( $p$ value = $0,571)$. Kondisi ini disebabkan oleh terpaparnya keluarga balita dengan informasi kesehatan terkait gizi yang dilakukan oleh tenaga kesehatan. Hasil penelitian ini didukung oleh penelitian Mirayanti (2012), bahwa tidak ada hubungan yang signifikan antara nilai dan keyakinan keluarga terhadap pola nutrisi dengan status gizi balita.

\section{Faktor dominan yang mempengaruhi status gizi balita}

Hasil analisis multivariat menunjukkan bahwa variabel yang paling berpengaruh terhadap gizi kurang pada balita adalah asupan makanan. Balita dengan asupan makanan yang kurang, berpeluang 11,9 kali untuk status gizi kurang dibandingkan dengan asupan makanan yang baik. Penelitian ini didukung oleh Putri dan Wahyono (2013), bahwa faktor langsung yang dominan berpengaruh terhadap kejadian wasting pada anak usia 24-59 bulan adalah asupan karbohidrat dengan OR 1,29. Anak dengan asupan karbohidrat yang kurang, beresiko menderita wasting 1,3 kali lebih besar dibandingkan dengan anak dengan asupan karbohidrat yang cukup.

Penelitian ini memiliki keterbatasan, diantaranya adalah dalam hal variabel asupan makanan. Variabel ini pengukurannya baru terbatas pada kecukupan kebutuhan energi saja, oleh karena itu diperlukan penelitian selanjutnya mengenai variabel asupan makanan yang dilihat dari kecukupan zat gizi lain seperti protein, vitamin dan mineral. Penelitian dengan metode kualitatif juga diperlukan untuk penelitian selanjutnya guna mendapatkan hasil penelitian yang lebih mendalam mengenai dimensi budaya kaitannya dengan status gizi balita.

\section{KESIMPULAN}

Faktor-faktor yang berhubungan secara bermakna dengan status gizi balita di wilayah Kulon progo, Yogyakarta adalah usia balita, riwayat pemberian ASI, asupan makanan, persepsi ibu terkait status gizi dan pola pengasuhan keluarga terkait gizi. Hasil penelitian ini menunjukkan angka kejadian gizi kurang di wilayah Kulon progo masih cukup tinggi bila dibandingkan dengan data kejadian gizi kurang balita dalam cakupan wilayah Provinsi D.I.Yogyakarta. Oleh karena itu angka kejadian gizi kurang di wilayah ini perlu mendapatkan perhatian bagi tenaga kesehatan.

Hasil penelitian ini dapat memberikan sumbangan informasi bagi pelayanan kesehatan dan keperawatan untuk dapat meningkatkan program gizi di masyarakat. Perlunya dilakukan penyuluhan secara berkala di pelayanan kesehatan dasar mengenai gizi pada balita sehingga dapat memperbaiki pola asuh, persepsi ibu yang kurang baik mengenai gizi pada balita dan perubahan perilaku keluarga menuju keluarga sadar gizi.

\section{UCAPAN TERIMAKASIH}

Ucapan terimakasih disampaikan kepada Kepala Puskesmas Sentolo1, keluarga balita yang berpartisipasi dan memberikan dukungan dalam penelitian ini.

\section{REFERENSI}

Almatsier. S. (2009). Prinsip dasar ilmu gizi (edisi ketujuh). Jakarta: Gramedia Pustaka Utama

Annim, S.K.,\&Imai K.S.,(2014. Nutritional status of children, food consumtion diversity and ethnicity in Lao PDR. Economics school of Social Sciece. University of Manchaster. UK

Bantamen, Belaynew, \& Dube (2014). Assessment of Factors Associated with Malnutrition among Under Five Years Age Children at Machakel Woreda, Northwest Ethiopia: A Case Control Study. Journal nutrition food science vol 4 No 12014

Charmarbaglawa,R.,Ranger.,M.,Waddington $\mathrm{H}$, White $\mathrm{H}$ (2010). The determination of child health and nutrition: a meta analysis. Departemen of economic, university of maryland and operation evaluation departement, world bank

Dinkes Kab Kulon Progo (2014). Profil Kesehatan Kabupaten Kulon progo Tahun 2014 (Data tahun 2013). Kulon Progo, DIY 
Handono, N.P (2010). Hubungan Tingkat Pengetahuan pada Nutrisi, Pola Makan, dan Tingkat Konsumsi Energi dengan Status Gizi Anak Usia Lima Tahun di Wilayah Kerja Puskesmas Selogiri, Wonogiri. Jurnal Keperawatan Vol 1 No.1, Juli 2010.

Hayati (2014). Analisis faktor orang tua terhadap status gizi balita. Pendekatan teori health belief model. Program studi ners Fakultas Keperawatan Universitas Airlangga.

Kartika, et al (2000). Pola pemberian makan anak (6-18 bulan) dan hubungannya dengan tumbang anak pada keluarga miskin dan tidak miskin. Jurnal Penelitian Gizi dan Makanan Jilid 23 Tahun 2000 Hal 37-47

Maseta, E., Makau K.W., \& Omwega A.M., (2008). Childcare practice and nutritional status of children aged 6-36 months among short ang long term beneficiaries of the child survival protection and development programmes (the case Morogoro, Tanzania). South Africa Journal of Clinical Nutrition. Vol 21, No 1, 2008

Mirayanti, N. (2012). Hubungan pola asuh pemenuhan nutrisi dalam keluarga dengan status gizi balita di Kelurahan Pasir Gunung Selatan Kecamatan Cimanggis Kota Depok. Tesis. Fakultas Ilmu Keperawatan Magister Ilmu Keperawatan: Depok.

Naghashpour et al (2014). Nutrition education based on health belief model improves dietary calcium intake among female students of junior high schools. Journal of Health Population Nutrition. Vol 32 , No 3, 420429 p. 2014

Nakamori et al (2010). Nutritional status, feeding practice and incidence of infectious disease among children aged 6 to 18 months in northern mountainous Vietnam. The journal of medical investigations vol. 57.2010

Putri, D.S.K \& Wahyono,T.Y.M (2013). Faktor langsung dan tidak langsung yang berhubungan dengan kejadian wasting pada anak umur 6-59 bulan di Indonesia tahun 2010. Media litbangkes Vol 23, No 3, September 2013, 110-121

Riskesdas. (2013). Riset Kesehatan Dasar 2013. Kementerian Kesehatan RI. https://www.litbang.depkes.go.id

Salehi et al (2004). Asessing the impact of nutrition education on growth of Iranian nomadic children: an application of a modified beliefs, attitudes, subjectives norms and enabling factors model. The British Journal of Nutrition, vol 91, 779p
Sartika, R. (2010). An anlysis on the usage of health service related to nutritional status of under five years old children. Jurnal Kesehatan Masyarakat Nasional Vol 5, No.2, Oktober 2010

Stanhope, M. \& Lancaster, J. (2012). Public Health Nursing Population Centered Health Care in The Community . $\left(8^{\text {th }} \mathrm{e}\right)$. Missouri: Elsevier.

Unicef (2011). Gender influences on child survival, health and nutrition:a narative review. New York

United Nations Children's Fund (UNICEF) (2013). Improving child nutrition: the achievable imperative for global progress, UNICEF, New York, 2013.

WHO (2013). The Millenium Development Goals (MDGs) Report 2013. United Nation New York.Diperoleh tanggal 25 Desember 2013 dari http://www.who.int/ nutrition/publications/severemalnutrition

Wong et al.(2014). Risk factors of malnutrition among preschool children in Terengganu, Malaysia: a case control study. BMC Public Health Journal 2014, 14: 785 